ljtihad: Jurnal Wacana Hukum Islam dan Kemanusiaan

Vol. 21, No. 2 (2021), pp. 135-154, doi : 10.18326/ijtihad.v21i2.135-154

\title{
The use of ex officio to fulfill women's post-divorce rights at the Samarinda Religious Court
}

\section{Lilik Andar Yuni}

Institut Agama Islam Negeri (LAIN) Samarinda

E-mail: lilikandaryuni@yahoo.com

DOI: 10.18326/ijtihad.v21i2.135-154

Problems in fulfilling women's rights after divorce in Religious Courts still exist due to the weakness of supporting elements for the court decisions and their procedures, and obstacles from the excouples. Therefore, religious judges are expected to have sensitivity and support for women in making decisions with the value of justice, legal certainty, and benefit. This normative juridical study used statutory and conceptual approaches to explain the use of ex officio in fulfilling iddah and mut'ah living in the Samarinda Religious Court and its suitability to legal purposes. A literary study was done in collecting data by compiling secondary data related to the theme. Then, the data were analyzed using the qualitative descriptive method. Ex officio discourses and legal objectives theory were used to analyze the raised issues. Fulfilling $i d d a b$ and mut'ab living through ex officio at the Samarinda Religious Court in talaq divorces refers to Supreme Court Regulation (PERMA) No. 3 of 2017, and Circular Letter of Supreme Court (SEMA) No. 1 of 2017. Meanwhile, the application of ex officio in lawsuit divorces refers to PERMA No. 3 of 2017 and SEMA No. 2 of 2019. The fulfillment of women's rights after divorce at the Religious Courts through ex officio aligns with legal objectives: legal certainty, justice, and benefit.

Pemenuhan hak perempuan pasca cerai di Pengadilan Agama menyisakan banyak problem, disebabkan lemahnya elemen pendukung putusan pengadilan dan prosedur pemenuhan hak-hak perempuan, kendala dari pihak mantan suami serta mantan istri. Oleh karena itu, hakim agama diharapkan memiliki sensitivitas dan keberpihakan pada perempuan, sehingga akan menghasilkan putusan yang bernilai keadilan, kepastian hukum dan kemanfaatan. Studi ini dimaksudkan untuk memberikan gambaran bagaimana penggunaan ex officio hakim dalam pemenuhan nafkah iddah dan mut'ah di Pengadilan Agama Samarinda serta bagaimana keselarasan penggunaan ex officio dengan tujuan hukum. Penelitian ini merupakan penelitian hukum yuridis normative, dengan pendekatan 
perundang-undangan dan pendekatan konseptual. Adapun teknik pengumpulan datanya dengan studi kepustakaan dengan cara mengumpulan data skunder terkait tema yang dikaji. Sementara analisis data dilakukan dengan cara deskriptif kualitatif. Diskursus ex officio dan teori tujuan hukum digunakan untuk menganalisis isu yang diajukan. Pemenuhan nafkah iddah dan mut'ah di Pengadilan Agama Samarinda pada putusan cerai talak melalui ex officio hakim merujuk pada Perma No. 3 Tahun 2017, SEMA No. 1 Tahun 2017 . Sedangkan penerapan ex officio hakim pada cerai gugat mengacu pada PERMA Nomor 3 Tahun 2017 dan SEMA No. 2 Tahun 2019. Pemenuhan hak perempuan pasca cerai di Pengadilan Agama melalui ex officio selaras dengan tujuan hukum, yakni kepastian hukum,keadilan dan kemanfaatan.

Keywords: ex officio; iddah living; mut'ah living

\section{Introduction}

Discussing women's rights always leads to debate regarding their position in the patriarchal culture, which justifies the hegemony of men over women (Rahmawati, 2020, p. 362) and justice, as they are part of the disadvantaged group. It is not just about their sexuality, but even more complex; they are placed in intersectional relationships related to race, class, colonialism, and naturism, in addition to poverty and underdevelopment (Hartanto \& Firdausy, 2014, p. 81).

Women's problems dealing with the law include: (1) lack of knowledge about legal rights; (2) limited funding; (3) barriers to communication; and (4) physical and mental barriers (Kelompok Kerja Perempuan, 2018, p. 5).

Courts are government institutions with the competence to resolve conflicts and disputes to achieve justice (Qabrati, 2020, p. 70). According to Jamilah, (2017, p. 91), The religious Court is the most influential institution to realize gender-just access and control over material and non-material rights. It is one of the law enforcement and justice institutions with authority in family law civil cases (Rinaldo, 2019, pp. 329-44), which are directly in contact with women's and children's rights. This is illustrated by the number of divorce cases submitted to the religious courts, as the number increases year by year (Djawas et al., 2021, p. 165). In 2018 the number of divorces was 444,358 cases, then in 2019 , it rose $12 \%$ to 480,618 cases. Meanwhile, the province with the highest divorce rates is East Java with 86,491 cases, followed by West Java with 75,001 cases, then Central Java with 71,373 cases (Rokan et al., 2020, p. 560). 
In talaq divorce, the ex-wife gets iddah, mut'ah and madhiyah living, and child support when there is no proof of nusyuz, as mandated in Article 149 of Compilation of Islamic Law (KHI). It also emphasizes that there is no guarantee of women's rights after divorce. This is reinforced by Article 41 (c) of Law No.1/1974, which explains that the wife will not get iddah living if she is nusyuz or gets divorced ba'in sughra. Despite a juridical norm that guarantees the protection of women and children right after divorce contained in these articles, there is still no guarantee for its fulfillment.

In 2018 , the number of divorces was 419,268, in which 307,778 cases were in lawsuit (Nasution \& Muchtar, 2020, p. 363). Suadi's research confirmed the randomly taken data of SIPP MARI from 1 January 2017 to 25 January 2018, that in the decision on talaq divorce 89,089 cases or about $88.84 \%$ were accompanied by granting the wife's rights (iddah, mut'ah and madhiyah living) either decided versteck.t or the presence of both parties (Suadi, 2018, p. 364). However, of the $88,43 \%$ above, only about $20 \%$ were realized voluntarily (Suadi, 2018 , p. 367). The data above shows that even in talaq divorce, where the women's post-divorce right is normatively regulated, there were only $20 \%$ fulfilled. Then the question arises on the fulfillment of women's rights in lawsuit divorce, which is not juridically regulated. In contrast, the number of lawsuit divorces is three times higher than talaq divorces.

The results of Stijn van Huis research quoted by Abu Rokhmat and Susilo indicated that the Religious Courts in Indonesia leave several problems for women related to the weak elements that support court decisions and procedures for fulfilling the rights of women and children after divorce by ex-husbands (Rokhmad \& Susilo, 2017, p. 494).

This paradigm underlies the expectations of the justice-seeking community towards the Religious Courts to: (1) enforce and apply the law based on supporting facts; (2) be more severe in dealing with the interests of women and children who are usually victims of divorce (Suadi, 2018, p. 355). This further emphasizes that judges in religious courts are tasked not only with divorcing couples, examining, adjudicating, and deciding cases that establish justice for the parties (Triana, 2018, p. 4), but also having sensitivity in supporting women's rights (Yuni \& Murjani, 2020, p. 253).

Because judges have an essential role in realizing justice and enforcing the law in the judicial process (Amarini, 2018, p. 301), they are expected to make decisions that guarantee 
legal certainty, justice, and benefits. Therefore, the role of the Religious Courts in women's rights is urgent.

Several researchers are focusing on women's rights in the Religious Courts, such as Suadi (2018), Mansari and Moriyati (2019), Fikhria (2018) in his study, Suadi emphasized the role of the Religious Courts in protecting the rights of women and children through a decision referring to PERMA No. 3 of 2017, while Fakhria focused on the difference in the number of rights obtained by wives in talaq and lawsuit divorces.

Meanwhile, previous studies on ex officio and talaq divorce can be seen in the research of Fanani and Ulfa (2018), Zulfa et al. (2020), Thariq (2019, p. 3), Labib (2017), Mahartika (2020). Zulfa stated that the judge's considerations in applying ex officio in talaq divorce included: (1) most of the wives (the Respondent) did not understand the law, so when the husband filed for divorce to the court, the wife did not personally or through their attorneys appear before the court; (2) the mandate of Law, namely Article 41 letter (c) Marriage Law No. 1 of 1974 and Article 149 letters a and b of the KHI; (3) the facts of the trial revealing that the husband could pay for the wife's rights (Zulfa, 2020, p. 5).

Meanwhile, research on ex officio and lawsuit divorce is seen in the study of Hikmatiar (2017) and Fuadi et al., (2021). Hikmatiar stated that the wife who filed for divorce would not get iddah living if she was nusyuz. However, in this study, the judge in the South Jakarta Religious Court gave it in a lawsuit divorce case through the application of ex officio because it was proven that the wife was not nusyuz (Hikmatiar, 2017).

This article was written to enrich several previous studies, especially regarding the use of judges ex officio and its relation to women's rights, especially the fulfillment of iddah and mut'ah living. This study was conducted to describe the ex officio discourse and the legal objectives theory, the problems of fulfilling women's rights after divorce in the Religious Courts, and the alignment of the use of ex officio in fulfilling iddah and mut'ah living with legal purposes.

\section{Method}

This normative juridical research examined and discussed legal science doctrines and principles using statutory and conceptual approaches. It was done by identifying the rules 
The use of ex officio to fulfill women's post-divorce rights at the Samarinda... (Lilik Andar Yuni)

regarding the protection of women's rights in the court, namely Law no. 1 of 1974, KHI, PERMA No. 3 of 2017 concerning Guidelines for Judging Women Dealing with Law, SEMA No. 1 of 2017, and SEMA No. 2 of 2019, as well as journals and articles regarding the protection of women's rights and their fulfillment in the Religious Courts.

The approach used in this study was conceptual and statutory, by examining Law no. 1 of 1974, KHI, PERMA No. 3 of 2017, SEMA No. 1 of 2017, SEMA No. 2 of 2019, and lawsuit talaq divorce decisions at the Samarinda Religious Court. The data collection technique was a literature study, by collecting secondary data in the form of primary legal materials, Law no. 1 of 1974, KHI, PERMA No. 3 of 2017 concerning Guidelines for Judging Women Dealing with Law, SEMA No. 1 of 2017, SEMA No. 2 of 2019 and the decision for the lawsuit and talaq divorce and at Samarinda Religious Court, and secondary journal material related to the themes studied.

The data collected were grouped and analyzed by qualitative descriptive analysis, by describing the data obtained from the literature review, conceptualizing, and concluding.

\section{Ex officio discourse and legal purpose}

The protection of women's post-divorce rights in the Religious Courts already has a good legal protection. The state has a significant role in realizing it, through various regulations issued. It is a state protection for its citizens, as an effort to prevent and suppress, both written and unwritten (Putri \& Amiruddin, 2020, p. 415).

Legal protection is intended to provide justice, order, certainty, benefit and peace, in line with the legal objectives (Djojorahardjo, 2019, p. 90). It is the government's effort to realize legal certainty and to provide legal protection to citizens, ensure that their rights are not violated, and those who do not obey the existing rules will be given sanctions.

The guarantee of the legal protection of women's rights after divorce in the Religious Courts can be seen in Article 49 of Law no. 1 of 1974 in conjunction with Article 149 letters (a) and (b), Articles 152 and 158 of the KHI. Articles 152 and 158 stipulate that rights cannot be fully obtained in divorce at the wife's initiative. Even if the rights are given, it cannot be fully because mut'ah is given only in talaq divorce as formulated in Article 158 of the KHI. 
Ijtihad: Jurnal Wacana Hukum Islam dan Kemanusiaan, Volume 21, No. 2, Desember 2021: 135-154

Other regulations are in the form of; first; jurisprudence (Cassation on the Decision no. $347 \mathrm{k} / \mathrm{Ag} / 2010,410 \mathrm{k} / \mathrm{Ag} / 2010$ and No. 137k/Ag/2007), regarding the legality of providing a living during the waiting period when the wife files a lawsuit, when she is not proven nusyur, and the use of ex officio in giving iddab living with the aim of istibra and also the interests of the husband.

Second, PERMA No. 3 of 2017, and third, in the form of SEMA including No. 1 of 2017, which explains the addition of clauses on payment of the right of $i d d a h$, mut'ah and madhiyah living which will be paid before the divorce pledge is stated, and SEMA No. 2 of 2019 which essentially reveals the decision in the divorce lawsuit to add a clause "paid before the Defendant takes the divorce certificate". SEMA No. 2 of 2019 is the application of progressive legal ideals and new hopes for wives who are currently litigating in the Religious Courts, both in the form of lawsuit divorce and khuluk so that their post-divorce rights will be fulfilled (Najichah \& Azizi, 2020, p. 56) .

The provision of living (iddah, madhliyah, and mut'ah) from the ex-husband to the exwife is carried out by the Religious Courts in two ways, namely; first, through ex officio as long as the wife is not proven to have committed nusyur; and second is reconvention (Suadi, 2018, p. 365).

Reconvention occurs if the wife understands her rights after divorce. Otherwise, the lawsuit is only limited to wanting a divorce. Under these conditions, judges are required to play an active role in making decisions that are more valuable in justice and benefit, especially for women. At this point, the use of ex officio is significant

The use of ex officio rights in making decisions in court has a fierce theoretical discussion because judges are considered to have carried out ultra petita, which seems to decide cases that exceed the demands of the litigating parties. If the decision states more than what was proposed by the parties, it is categorized as a poor decision, even though it is intended for more significant benefit, but is considered an unjustified act (Zulfa et al., 2020). Article 189 (3) Rbg. Jo Article 178 (3) of Herzien Inlandsch Reglemen (HIR) confirms that the judge in deciding the existing dispute cannot exceed the lawsuit materials or known as utra partium petitum. The principle of utra petita is intended as a form of determination for judges not to make decisions not requested by Plaintiff/Applicant 
In the civil realm, the extent of the case depends on the parties, so the judge is passive. Individual rights within the scope of civil law get high guarantees, and even if there is an ultra petita in decisions that have been inkracht (legally binding), the Supreme Court can cancel it (Subagyono et al., 2014, p. 103).

Violation of the ultra petita principle is identical to deviation from the rule of law because: (1) one of the principles explains that every judge's actions must be in line with existing norms (accordance with the law), and (2) exceeding the existing competencies (Article 178 paragraph 3 of HIR) (Fadhilah, 2019, p. 75).

Although ultra petita decisions are still debatable in the civil realm, the Supreme Court allows decisions to contain ultra petita with legal considerations: (1) there is a strong correlation; (2) judges must strive to resolve cases as well as possible; (3) there is relevance to the lawsuit material; (4) to get the value of justice following the essence of the initial lawsuit (Fadhilah, 2019, p. 81).

Ex officio are rights owned by judges because of their position to resolve conflicts, which are not following standard normative procedures. This means that in the use of ex officio, the decision contains an ultra petita, as the decision exceeds what Plaintiff requested. The ex officio application of judges is very urgent, especially in divorce cases. In a divorce case, a judge is allowed to decide something not requested by the parties.

The logical arguments built in the application of ex officio in divorce cases are: (1) Article 41 of Law no. 1/ 1974; (2) judges make law, so they must perform ijtihad and play an active role in finding the law; (3) the authority to contra legume because the existing legal rules are not appropriate.

Fanani (2018, p. 347) stated that the use of ex officio is intended to: (1) ensure the life of ex-wife after divorce; (2) the husband does not arbitrarily divorce his wife; (3) provide justice for the wife due to talaq divorce; (4) economically the husband can pay a living. It was further said that several circumstances made it impossible to apply ex officio, namely: (1) before sexual intercourse; (2) the wife is sentenced to ba'in or nusyur, (3) the wife states that she does not want the rights; (4) ex-husband does not have the economic capacity to fulfill ex-wife's rights (Fanani, 2018, p. 347). 
The application of ex officio rights is intended to balance court decisions. This means that judges can issue decisions that have fair value. If a husband divorces his wife and ignores her rights, the judge can guarantee the fulfillment of these rights by applying ex officio rights (Labib, 2017, p. 113).

The judge's decision must be in line with the legal objectives, namely; legal certainty, justice, and benefits aspects (Yunanto, 2019, pp. 202-203). The value of certainty is a value that in principle provides legal protection for every citizen from arbitrary actions so that the law gives the state responsibility to run it. A legal certainty is a form of legal embodiment that is certain, concrete, and unaffected by anything (Julyano \& Sulistyawan, 2019, pp. 14-15).

Justice demands that people treat each other according to their rights and obligations. The treatment is not indiscriminate or favoritism; instead, everyone is treated equally according to their rights and obligations (Hikmatiar, 2017, p. 153).

The benefit is the most important thing in a legal purpose. Benefit can be interpreted as happiness. The good or bad of a law depends on whether the law gives happiness to humans or not. Law is for humans, so the implementation or enforcement of the law must provide benefits to humans/society.

The benefit criteria include; (1) giving happiness or satisfaction to the litigants; (2) resolving new polemics or conflicts for the parties; (3) good relations between the disputing parties; (4) giving back the right for the winner; and (5) creating balance in society.

\section{The problems of fulfilling women's rights in the court}

Women's rights guaranteed in court decisions, in its implementation, leaves many problems because they are often not fulfilled.

In general, the implementation of a divorce decision accompanied by husbands' obligation to pay for iddah, mut'ah, and madhliyah living in the Religious Courts is realized in two ways, namely voluntary implementation and execution mechanism by the Court. However, execution cannot be a solution because the procedures and costs required for execution are greater and not proportional to the amount of living required (Syahr, 2019, p. 21). 
Voluntary implementation is emphasized. However, in reality, it does not show a significant number, only in the range of $20 \%$ of the $88.43 \%$ of talaq divorce decisions accompanied by the obligation on the husband (Suadi, 2018, p. 367).

That happens because: (1) the Religious Courts do not have the authority to force a person to carry out the task, unless the woman submits a request for execution of the decision (Suadi, 2018, p. 368); (b) the cost of execution is not proportional to the object to be executed.

Barriers in fulfilling the rights of women and children in the Religious Courts can be divided into at least three, namely First: obstacles from the ex-husband: (a) the husband ignores the decision of the Religious Court and leaves his residence and his whereabouts are unknown; (b) the ex-husband does not have a steady income or his assets are not sufficient for execution (Sholeh et al., 2019, pp. 86-87).

Second, obstacles from the ex-wife: (a) women's knowledge and understanding of their rights is still low (Sholeh et al., 2019, p. 87); (b) women do not know the process and procedures to obtain their rights so that the material for the lawsuit is minimal and tends to harm women; (c) varying level of education and economy, so that women find it challenging to file applications/claims.

Third, from regulatory factors: (a) there is no firm sanction for the ex-husband ignoring the court's decision; (b) there is no mechanism that binds third parties to ensure the payment of living by absentee parties (Irawan, et.al, 2019, pp. 42-43).

\section{The use of ex officio in fulfilling iddah and mut'ah living at the Samarinda Religious Court}

The use of ex officio at the Samarinda Religious Court in fulfilling iddah and mut'ah living is seen in Talaq Divorce Decision No. 1208/Pdt.G/2021/PA.Smd. The rights obtained by the ex-wife are: (a) iddah living of Rp 3,000,000; (b) madhiyah living of Rp 1,000,000

Meanwhile, in the Talaq Divorce Decision No. 1132/Pdt.G/2021/PA.Smd., the rights obtained are: (a) iddah living of Rp3,000,000; (b) mut'ah living of Rp3,000,000; (c) children's income of Rp2,000,000 every month with an increase of 10\% until the child grows up.

The two examples above describe that the rights of women and children after divorce are accommodated through ex officio. Those decisions also show that the post-divorce rights 
Ijtihad: Jurnal Wacana Hukum Islam dan Kemanusiaan, Volume 21, No. 2, Desember 2021: 135-154

obtained from each case depend on each party's conditions and the amount is also different. However, it can be concluded that the rights accommodated include: (1) iddah living; (2) mut'ah living; (3) hadhanah living; and (4) child support. Several talaq divorce decisions also state, "submitted in cash when the talaq pledge is executed". It is in line with PERMA No. 3 of 2017 concerning Guidelines for Judging Women Dealing with Law. Among the principles contained therein is to protect women's rights in court. It is also in line with SEMA No. 1 of 2017, that the fulfillment of obligations is included in the decision with the clause, "paid at the time of taking the divorce pledge."

The inclusion of "submitted in cash at the time the talaq pledge is executed" means that the divorce pledge and the fulfillment of the rights are unified obligations, in the sense that the divorce vow will not be read out until the husband fulfills his obligations to his ex-wife, with the six-month deadline for repayment. Payment of iddah and mut'ah living before uttering divorce pledge, apart from being an anticipatory step against the former husband's reluctance to carry out his obligations, with various factors and reasons, provides more guarantees of legal protection for women and children after divorce, not only in the decision but also in providing legal protection for women and children.

Meanwhile, the application of ex officio in lawsuit divorce cases can be seen in the following Decisions:

1) No.1726/Pdt.G/2021/PA.Smd. The right accommodated is the iddab living of $\mathrm{Rp}$ 15,000,000 paid every month Rp 5.000.000 for three months.

2) No.1042/Pdt.G/2021/PA.Smd, decided versteck.t. The right accommodated are: (a) Monthly living of the two children is Rp 3,000,00 until they are adult; (b) iddah living of Rp 3,000,000 (b) mut'ah living of Rp 750,000

3) No.1131/Pdt.G/2021/PA.Smd, decided versteckt. The rights accommodated are: (a) iddah living of Rp 3,000,000 (b) mut'ah living of Rp 2,000,000

Observing the three divorce decisions above is quite encouraging because women's rights are well guaranteed through ex officio. The rights obtained are not only iddah but also mut'ah living. This is interesting because judges rarely sue for divorce decisions using ex officio, it is not even applied, because when the wife files for divorce, there is no obligation of the ex-husband to provide a living, because there is no reconciliation (Mahartika, 2020, 
p. 53). The form of lawsuit divorce is ba'in, so the husband is not obliged to provide mut'ah and iddah living (Najichah \& Azizi, 2020, p. 54). In addition, it is considered as a form of rebellion by the wife to break away from the marriage bond with her husband. As a result, the wife does not get her rights in full or even does not get it at all (Fakhria, 2018, p. 118).

It is seen that the provision of $i d d a h$ and mut'ah in the lawsuit divorce decision at the Samarinda Religious Court through the ex officio refers to the Cassation Decision No. 347 k/Ag/2010, No. 410k/Ag/2010, No. 276k/Ag/2010, concerning the legality of providing iddah living in a lawsuit divorce case as long as the wife is proven not to be nusyuz and PERMA No. 3 of 2017 as well as SEMA No. 3 Year 2018 points (3).

The cases above also describe that women's rights are guaranteed through ex officio, two of which were decided versteckt. The Versteckt's decisions happen $70 \%$ in lawsuit divorce (Susantin, 2020, p. 203). This is reinforced by the results of Faisol's research in Malang Religious Court, in April 2019 the number of divorce decisions was 687, and 442 were decided versteckt (Rochman et al., 2019, p. 13).

There were several reasons behind the absence of the Defendants at the trial, including (1) They want a quick divorce; (2) Unknown address; (3) They do not want a divorce; (4) They don't want to be complicated with court matters but want a divorce ((Rochman et al., 2019, pp. 6-15); (5) They agree to divorce but is reluctant to pay court fees (Waluyo, 2019, p. 111).

Looking at case No. 1042/Pdt.G/2021/PA.Smd. and 1131/Pdt.G/2021/PA.Smd. The Defendant's address and place of work were precise, but he did not want to be bothered with court matters and wanted a quick divorce. the Defendant was present at the beginning of the mediation process but not in the trial process until the decision. However, through ex officio, the judge sentenced (1) Custody of the child in the Plaintiff's hands; (2) the living for 2 children of Rp 3,000,000 every month; (3) Iddah living for Rp 3,000,000; and (4) Mut'ah living for Rp 750,000. The judge's consideration for Defendant is because of his financial ability as he works in Public Department with a salary of Rp 4,100,000 per month and from the chronology of the case, the wife is not nusyur. The divorce happens the Defendant ignores his family and rarely returns home. 
ljtihad: Jurnal Wacana Hukum Islam dan Kemanusiaan, Volume 21, No. 2, Desember 2021: 135-154

Meanwhile, in the Decision No.1131/Pdt.G/2021/PA.Smd., decided without the Defendant's presence (because he was not present from the beginning), through ex officio,

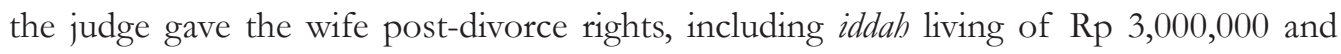
mut'ah living of Rp 2.000.000. The judge's considerations in this decision are (1) PERMA No. 3 of 2017 concerning Guidelines for Judging Women Dealing with the Law; (2) the husband is economically capable because the Defendant is a civil servant; (3) the wife is proven not to do nusyur, because the divorce stems from the husband's selfishness.

In Decision No. 1726/Pdt.G/2021/PA.Smd (attended by Plaintiff and Defendant) and 1042/Pdt.G/2021/PA.Smd. (versteckt) the rights obtained are $i d d a h$ and mut'ah living. However, unfortunately, the two decisions did not include "paid before Defendant takes the divorce certificate". Because the decision said so, the ex-wife's hope of living during her iddah was not fulfilled. The decision just stopped on a piece of paper (Darmawati, 2020, p. 55). Benevolence and justice as legal objectives do not work well because the wife's rights are not appropriately fulfilled (Adnya \& Musarrofa, 2017, pp. 309-310).

In contrast to decision No. 1131/Pdt.G/2021/PA.Smd includes the sentence "paid before the defendant takes the divorce certificate." This is as confirmed in SEMA No. 2 of 2019 and in the context of implementing PERMA No. 3 of 2017. This SEMA is a solution that has been faced by ex-wives related to the problem of executing post-divorce rights, and guaranteeing the ease of fulfilling them (Najichah \& Azizi, 2020, p. 57).

The application of ex officio judges in fulfilling iddah and mut'ah living several examples above, are they contrary to the ultra petita principle? Although the ultra petita principle and the judge's ex officio rights seem contradictory, they have a reasonably harmonious relationship. Ultra petita is a form of limitation for judges not to make decisions other than those proposed by the parties. Meanwhile, ex officio is an inherent competence by judges as their position to make decisions that exceed demands as an embodiment of justice and protection for litigants.

The decision above, deciding the Petitioner/Plaintiff to provide iddah and mut'ah to the Respondent/Defendant, is categorized as ultra petita because the judge decides to exceed what is requested by the Petitioner. 
As previously explained, a decision may contain an ultra petita, with the following conditions: (1) there are logical considerations; (2) the judge tries his best to resolve the case; (3) there is relevance to the material of the lawsuit; (4) to get the value of justice following the essence of the initial lawsuit (Fadhilah, 2019, p. 81).

So, the application of ex officio in both the talaq and lawsuit divorce does not contradict or violate the ultra petita principle, because: (1) in the legal considerations it includes Article 41 (c), PERMA No. 3 of 2017, SEMA 1 of 2017, SEMA 3 of 2018; (2) the judge makes every effort to produce the best decision for both parties, by granting rights to the litigants; (3) the provision of iddah and mut'ah by the judge even though it is not requested or demanded by the Parties (Plaintiff/Defendant) is related the divorce case filed by the Plaintiff/Applicant, in which the consequence of divorce is that the husband is obliged to provide a living (iddah, mut'ah, madhiyah, and child support); (4) the provision of iddah and mut'ab living in talaq and lawsuit divorce ex officio provides more justice for the parties and this is following the intent of the lawsuit to get the fairest decision.

Referring to Fanani's research, the application of ex officio in fulfilling iddah and mut'ah living has been justified, because: (1) from the examples in both divorces, the couple has had sexual intercourse and they have children; (2) the wife is not nusyur, because, it is proven that the cause of the divorce is the husband who commits domestic violence or has an affair; (3) the wife wants these rights; (4) ex-husband has the financial ability to pay for these rights (Fanani, 2018, p. 347).

The judge's decision is the law. Judges in making decisions do not only look at the law (the denken system), but also have to ask their conscience by paying attention to justice and expediency when the decision has been handed down (problem denken). As a law, the judge's decision must be able to realize the purpose of the law itself, namely justice, certainty and benefit, because the fundamental value of law includes at least three values, namely justice, benefits, and legal certainty (Julyano \& Sulistyawan, 2019, p. 13).

The use of ex officio in the Samarinda Religious Court in divorce decisions above has automatically provided legal certainty because the wife's fate becomes clear. As the purpose of the law is to provide protection and certainty, with the divorce decision providing certainty for the wife whose fate is hanged by her husband, it shows the clarity of women's 
Ijtihad: Jurnal Wacana Hukum Islam dan Kemanusiaan, Volume 21, No. 2, Desember 2021: 135-154

status in society. In addition, by including normative rules in Law Number 1 of 1974 , PERMA and SEMA in the considerations, it also guarantees legal certainty because they contain juridical values.

It also contains the value of the benefit, because the provision of a living, besides being consolation strengthening the ex-wife, it is also a form of legal protection for divorced women so that they are not financially deprived due to unfavorable conditions. (Rohman et al., 2020, p. 303), In addition, it also provides benefits for the wife because it has provided happiness. The divorce decision makes the wife sad, but the judge is recommended to give the ex-wife's rights to reduce the sadness. When the wife does not ask for it, the judge with the attached position can give it through ex officio. Because the granting of these rights and providing benefits to the ex-wife, also provides consolation on the other side. Because, after all, expediency is the most important thing in legal purposes. The indicator of whether the decision is good or not is whether it gives happiness for the parties involved. The law is for humans, so its implementation must also benefit humans.

This is in line with the usefulness parameters, including; (1) providing happiness and satisfaction for the parties, (2) resolving new conflicts for the parties, (3) the rights and obligations of the parties have been obtained (Mahmudah, 2019, p. 115).

In addition to providing certainty and benefit, the use of ex officio in the decisions at Samarinda Religious Court also has the value of justice because the divorced wife gets a divorce certificate, and more than that, she also gets her rights. So it provides more balance and has justice value because it guarantees the fulfillment of the rights of women and children (Labib, 2017, p. 113).

It can be concluded that the use of ex officio in the example of talaq divorce decisions above, is in line with the objectives of the law, namely justice, legal certainty, and benefits. Meanwhile, in the divorce decision, as described previously, when the injunction includes the sentence, "before the defendant takes the Divorce Certificate," the decision follows legal objectives. When the sentence does not include the sentence, it can be said that the decision only provides legal certainty, because basically, when the marriage certificate is obtained, the wife's fate becomes clear. At the same time, justice and benefit are not guaranteed if the fulfillment of the wife's rights is only limited to a decision on paper. 
As the main actors in law enforcement, judges in making decisions must at least reflect the legal objectives, namely justice, certainty, and benefits. However, it is common for the three objectives of the law to be harmoniously correlated. On the contrary, they confront and contradict each other. If it happens, then justice is the priority (Rizkiana, 2020, pp. 570-71), because law equals justice. There is no law without justice (Mukhlishin, Sarip, 2020, p. 56).

\section{Conclusion}

The use of ex officio in fulfilling iddah and mut'ah living in in talaq and lawsuit divorce at the Samarinda Religious Court does not contradict the ultra petita principle because it includes; (1) the logical considerations; (2) the best effort of judges to make the best decisions; (3) the relevance to the lawsuit materials; (4) worth justice.

The application of ex officio at the Samarinda Religious Court which decided the Petitioners and Defendants to provide $i d d a b$ and mut'ab living and their harmony with legal objectives can be sorted as follows: In the two talaq divorce decisions used as examples in this study, all of them include a clause, "paid before the divorce pledge is stated. This is in line with the objectives of the law, namely justice, legal certainty, and benefits. Meanwhile, from the three examples of divorce decisions, two of them, on their commands, stated, "to be paid when the Defendant takes the divorce certificate". This decision is more in line with the objectives of the law.

This is an initial study for the East Kalimantan region, and there are still many shortcomings and weaknesses. Further research is needed with the same theme but with a broader range of locations to refine it.

\section{References}

Adnya, S., \& Musarrofa, I. (2017) "Analisis Yuridis Pandangan Hakim Pengadilan Agama Sukoharjo terhadap Pelaksanaan Putusan Tuntutan Nafkah Pasca Cerai'. Al-Hukama' : The Indonesian Journal of Islamic Family Law, 7(2), 57-84. https://doi.org/10.15642/alhukama.2017.7.2.57-84

Amarini, I. (2018) Generating A High Quality and Integrity Career Judges Recruitment PostConstitutional Court Decision Number 43/PUU-XIII/2015 S. 18(3), 8. 
Ijtihad: Jurnal Wacana Hukum Islam dan Kemanusiaan, Volume 21, No. 2, Desember 2021: 135-154

Darmawati, A. (2020) "Kepastian Hukum Pelaksanaan Sita Jaminan oleh Pengadilan Negeri Balikpapan (Studi Analisis Perkara Nomor: 80/Pdt.G/2001/PN.Bpp)". LEX SUPREMA Jurnal Ilmu buk.um, 2(1). https://jurnal.law.uniba-bpn.ac.id/index.php/ lexsuprema/article/view/275

Djawas, M., Ridhwan, R., Devy, S., \& Husna, A. (2021) “The Government's Role in Decreasing Divorce Rates in Indonesia: The Case of Aceh and South Sulawesi". AHKAM : Jurnal Ilmu Syariah, 21(1), Article 1. http://journal.uinjkt.ac.id/index.php/ ahkam/article/view/20870

Djojorahardjo, R. H. (2019) "Mewujudkan Aspek Keadilan dalam Putusan Hakim di Peradilan Perdata". JURNAL MEDLA HUKUM DAN PERADIL AN, 5(1), 88-100. https://doi.org/10.29062/jmhp.v5i1.79

Fadhilah. (2019) 'Ultra Petitum Partium dalam Perkara Perceraian Menurut Hukum Acara Peradilan Agama dan Yurisprudensi Mahkamah Agung”. FITRAH: International Islamic Education Journal, 1(2), Article 2. https://journal.ar-raniry.ac.id/index.php/ fitrah/article/view/574

Fakhria, S. (2018) "Cerai Gugat dan Implikasinya terhadap Hak-hak Finansial Perempuan”. Legitima: Jurnal Hukum Keluarga Islam, 1(1), 91-119. https://doi.org/10.33367/ legitima.v1i1.648

Fanani, A. (2018) "Hak Ex Offcio Hakim: Studi Kasus Perceraian di Pengadilan Agama Sidoarjo No. 3513 Th. 2015”. TSAQAFAH, 13(2), 339. https://doi.org/10.21111/ tsaqafah.v13i2.1091

Fuadi, A. S., Saputra, D. E., \& Munajah, M. (2021) "Analisis Yuridis Hak Ex Officio Hakim dalam Perkara Cerai Gugat (Studi Kasus Putusan Pengadilan Agama Martapura Nomor 318/Pdt.G/2020/PA.Mtp)". Jurnal Penegakan Hukum Indonesia, 1 (1). https:/ / doi.org/10.51749/JPHI.V1I1.21

Hartanto, R. V. P., \& Firdausy, A. G. (2014) "Paralegal dan Akses Perempuan terhadap Keadilan: Kajian tentang Peranan Paralegal dalam Pemberdayaan Hukum untuk Meningkatkan Akses Perempuan terhadap Keadilan”. Yustisia Jurnal Hukum, 3(2), Article 2. https://doi.org/10.20961/yustisia.v3i2.11098

Hikmatiar, E. (2017) “Nafkah Iddah pada Perkara Cerai Gugat”. MIZAN, 3(1), Article 1. 
The use of ex officio to fulfill women's post-divorce rights at the Samarinda... (Lilik Andar Yuni)

http://ejournal.uika-bogor.ac.id/index.php/MIZAN/article/view/368

Irawan, Syahr, Gilang, M., Zulfa, Sr. (2019) Perlindungan Hak Perempuan dan Anak Melalui

Putusan Pengadilan Agama [Online]. Available at: https://bldk.mahkamahagung.go.id/

id/unduh-materi/download/90-2019/1657-perlindungan-hak-perempuan-dan-

anak-melalui-putusan-pengadilan-agama

Jamillah, Hj. (2017) "Judges According to Islamic Law and Indonesian Law in Islamic Court". IOSR Journal of Humanities and Social Science, 22(01), 87-93. https://doi. org/10.9790/0837-2201068793

Julyano, M., \& Sulistyawan, A. Y. (2019) "Pemahaman terhadap Asas Kepastian Hukum Melalui Konstruksi Penalaran Positivisme Hukum”. Crepido, 1(1), 13-22. https://doi. org/10.14710/crepido.1.1.13-22

Labib, A. Z. H. (2017) “Hak Ex Officio Haki Pengadilan Agama Wamena dalam Perkara Nafkah Pasca Perceraian”. Journal de Jure, 9(2), 106-116. https:// doi.org/10.18860/jfsh.v9i2.6919

Mahartika, D. (2020) "Ratio Decidendi Majelis Hakim tentang Hak Ex Officio Hakim dalam Memberikan Hak Asuh dan Nafkah Anak Pada Perkara Cerai Talak”. UNISKA LAW REVIEW, 1(2), 40-60. https://doi.org/10.32503/ulr.v1i2.177

Mahmudah, N. (2019) "Aspek Sosiologis dalam Putusan Pengadilan dada Perkara Cerai Gugat”. Nizham Journal of Islamic Studies, 7(01), 106-122.

Mansari, M., \& Moriyanti, M. (2019) "Sensitivitas Hakim terhadap Perlindungan Nafkah Isteri Pasca Perceraian”. Gender Equality: International Journal of Child and Gender Studies, 5(1), 43-58. https:/ / doi.org/10.22373/equality.v5i1.5377

Mukhlishin, Sarip, M. S. (2020) "Keadilan dan Kepastian Hukum: Menyoal Konsep Keadilan Hukum Hans Kelsen Perspektif "Al-'Adl" dalam al-Qur'an". Media Keadilan: Jurnal Ilmu Hukum, 11 (1). https://scholar.google.co.id/ citations?view_op=view_citation\&hl=en\&user=AucfvPwAAAAJ\&citation_for_ view $=$ AucfvPwAAAAJ:YsMSGLbcyi4C

Najichah, N. N., \& Azizi, A. Q. (2020) “Implikasi Inisiatif Perceraian terhadap Hak Nafkah Istri”. Journal of Islamic Studies and Humanities, 5(1), 42-60. https://doi.org/10.21580/ jish.v5i1.6960 
Ijtihad: Jurnal Wacana Hukum Islam dan Kemanusiaan, Volume 21, No. 2, Desember 2021: 135-154

Nasution, H., \& Muchtar, A. R. (2020) "Access to Justice for Women and Children in Divorce Cases in the Indonesian Religious Courts". AHKAM : Jurnal Ilmu Syariah, 20(2), Article 2. http://journal.uinjkt.ac.id/index.php/ahkam/article/view/15702

Oleh, D. (2018) Pedoman Mengadili Perkara Perempuan Berhadapan dengan Hukum. 90.

Putri, R. E., \& Amiruddin, M. (2020) "Perlindungan Hukum bagi Perempuan di Hadapan Hukum". Alauddin Law Development Journal, 2(3), 413-420.

Qabrati, I. (2020) "The Concept of Law and Justice". PRIZREN SOCIAL SCIENCE JOURNAL, 4(3), 69-73. https://doi.org/10.32936/pssj.v4i3.188

Rahmawati, S. (2020) "Mainstreaming of Gender Equality in Islamic Family Law: Opportunities and Challenges". Samarah: Jurnal Hukum Keluarga Dan Hukum Islam, 4(2), 360-374. https:// doi.org/10.22373/sjhk.v4i2.8110

Ratio Decidendi Majelis Hakim tentang Hak Ex Officio Hakim dalam Memberikan Hak Asub dan Nafkah Anak Pada Perkara Cerai Talak | UNISKA LAW REVIEW. (n.d.). Retrieved April 21, 2021, from https://ejournal.uniska-kediri.ac.id/index.php/SJ/article/ view/177

Rinaldo, R. (2019) "Obedience and Authority among Muslim Couples: Negotiating Gendered Religious Scripts in Contemporary Indonesia”. Sociology of Religion, 80(3), 323-349. https://doi.org/10.1093/socrel/sry045

Rizkiana, A. E. (2020) “Diskresi Hakim dalam Perkara Perceraian dan Hak Asuh Anak (Studi di Pengadilan Negeri Pati)". Notarius, 13(2), 865-878. https://doi.org/10.14710/nts. v13i2.31288

Rochman, F. F., Faisol, A., \& Rodafi, D. (2019) "Analisis Putusan Versteckt dalam Perkara Perceraian Studi Kasus di Pengadilan Agama Kabupaten Malang”. Jurnal Hikmatina, $1(2), 12-17$.

Rohman, A. N., Sugeng, \& Widyaningrum, H. (2020) "Instrumentation Of Ex-Officio Rights of Religious Courts Judge Related to Fulfilling Children and Wife's Rights Due to Divorce". Jurnal Hukum \& Pembangunan, 50(2), 361-378. https:/ / doi.org/10.21143/ jhp.vol50.no2.2581

Rokan, M. K., Yazid, I., \& Makky, A. (2020) "Reconstruction of the Concept of Nushuz of the Wife in the Digital Era". Samarah: Jurnal Hukum Keluarga Dan Hukum Islam, 4(2), 
The use of ex officio to fulfill women's post-divorce rights at the Samarinda... (Lilik Andar Yuni)

568-585. https://doi.org/10.22373/sjhk.v4i2.7259

Rokhmad, A., \& Susilo, S. (2017) "Conceptualizing Authority of The Legalization of Indonesian Women's Rights in Islamic Family Law”. JOURNAL OF INDONESIAN ISLAM, 11(2), 489-508. https://doi.org/10.15642/JIIS.2017.11.2.489-508

Sholeh, A., Rachmat Gumelar, D., \& Tsamrotul Fuadah, A. (2019) "Pendampingan Hakhak Perempuan dan Anak Pasca Perceraian”. JCIC : Jurnal CIC Lembaga Riset dan Konsultan Sosial, 1(2), 80-99. https://doi.org/10.51486/jbo.v1i2.19

Suadi, A. (2018) "Peranan Peradilan Agama dalam Melindungi Hak Perempuan dan Anak Melalui Putusan yang Memihak dan dapat dilaksanakan / The Role of Religious Court In Women and Children Rights Protection Through Partial and Executable Decision". Jurnal Hukum dan Peradilan, 7(3), 353-374. https://doi.org/10.25216/ JHP.7.3.2018.353-374

Subagyono, B. S. A., Wahyudi, J., \& Akbar, R. (2014) "Kajian Penerapan Asas Ultra Petita pada Petitum Ex Aequo Et Bono”. Yuridika, 29(1), Article 1. https://doi. org/10.20473/ydk.v29i1.360

Susantin, J. (2020) "Analisis Putusan Verstek dalam Perkara Cerai Gugat Perspektif Maslahah Mursalah”. Jurnal YUSTITIA, 20(2), Article 2. https://doi.org/10.0324/ yustitia.v20i2.695

Syahr, Z. (2019). Implementasi Perlindungan Hak Perempuan dan Anak dalam Putusan Pengadilan Agama (pp. 17-31).

Thariq, M. A. (2019) “Hak Ex Officio Hakim: Pertimbangan Hukum Hakim terhadap Pembebanan Nafkah Iddah dan Mut'ah dalam Perkara Cerai Talak Verstek Perspektif Maqashid Syariah (Kasus di Pengadilan Agama Kabupaten Malang)". Sakina: Journal of Family Studies, 3(2), Article 2. http://urj.uin-malang.ac.id/index.php/jfs/article/ view/264

Triana, N. (2018) "Progressivity of Judges in Domestic Violence Disputes Settlement in The Case of Divorce in The Religious Court". Ulul Albab: Jurnal Studi Dan Penelitian Hukum Islam, 2(1), 1. https://doi.org/10.30659/jua.v2i1.3543

Waluyo, S. (2019) “Kesepakatan Para Pihak Sebagai Upaya Mencapai Putusan Verstek dalam Perkara Perceraian (Study Kasus di LBH SAKTI Purworejo)”. Isti dal : Jurnal 
Ijtihad: Jurnal Wacana Hukum Islam dan Kemanusiaan, Volume 21, No. 2, Desember 2021: 135-154

Studi Hukum Islam, 6(2), 101-117. https:/ / doi.org/10.34001/istidal.v6i2.1613

Yunanto, Y. (2019) "Menerjemahkan Keadilan dalam Putusan Hakim". Jurnal Hukum Progresif, 7(2), 192-205. https://doi.org/10.14710/hp.7.2.192-205

Yuni, L. A., \& Murjani, M. (2020) “Gender Sensitivity at Judge's Verdicts in Samarinda and Magelang Religious Courts; The Implementation of PERMA Number 03 of 2017”. AL-IHKAM: Jurnal Hukum \& Pranata Sosial, 15(2), 251-279. https://doi. org/10.19105/al-lhkam.v15i2.2714

Zulfa, N., Faisol, A., \& Kurniawati, D. A. (2020) "Penerapan Hak Ex Officio Hakim dalam Perkara Cerai Talak (Studi Putusan Pengadilan Agama Kabupaten Malang Nomor 3645/Pdt.G/2019/Pa.Kab.Mlg)". Jurnal Hikmatina, 2(3), 156-166. 